\title{
Postherpetic neuralgia: epidemiology, pathophysiology, and pain management pharmacology
}

This article was published in the following Dove Press journal:

Journal of Multidisciplinary Healthcare

21 September 2016

Number of times this article has been viewed

\author{
Theresa Mallick-Searle' \\ Brett Snodgrass ${ }^{2}$ \\ Jeannine $M$ Brant $^{3}$ \\ 'Pain Management Center, Stanford \\ Health Care, Redwood City, CA, \\ ${ }^{2}$ LifeLinc Pain Centers, Cordova, TN, \\ ${ }^{3}$ Billings Clinic, Billings, MT, USA
}

\begin{abstract}
Herpes zoster, also known as shingles, is a distinctive clinical condition caused by the reactivation of latent varicella zoster (chickenpox) virus following an initial infection. Approximately 1 million cases of herpes zoster occur annually in the US, and one in every three people develops herpes zoster during their lifetime. Postherpetic neuralgia is a neuropathic pain syndrome characterized by pain that persists for months to years after resolution of the herpes zoster rash. It stems from damage to peripheral and central neurons that may be a byproduct of the immune/inflammatory response accompanying varicella zoster virus reactivation. Patients with postherpetic neuralgia report decreased quality of life and interference with activities of daily living. Approaches to management of postherpetic neuralgia include preventing herpes zoster through vaccination and/or antiviral treatment, and administering specific medications to treat pain. Current guidelines recommend treatment of postherpetic neuralgia in a hierarchical manner, with calcium channel $\alpha 2-\delta$ ligands (gabapentin and pregabalin), tricyclic antidepressants (amitriptyline, nortriptyline, or desipramine), or topical lidocaine patches as first-line drugs. The safety and tolerability of pharmacologic therapies for pain are important issues to consider as postherpetic neuralgia affects primarily an older population. Patients should be educated on appropriate dosing, titration if applicable, the importance of adherence to treatment for optimal effectiveness, and possible side effects. Health-care professionals play a key role in helping to ameliorate the pain caused by postherpetic neuralgia through early recognition and diligent assessment of the problem; recommending evidence-based treatments; and monitoring treatment adherence, adverse events, responses, and expectations. Nurse practitioners are especially crucial in establishing communication with patients and encouraging the initiation of appropriate pain-relieving treatments.
\end{abstract}

Keywords: postherpetic neuralgia, herpes zoster, shingles, gabapentin, pregabalin, tricyclic antidepressants

\section{Introduction}

Postherpetic neuralgia (PHN) is a neuropathic pain syndrome characterized by pain that persists for months to years after resolution of the herpes zoster (HZ) rash. ${ }^{1-3}$ $\mathrm{HZ}$, also known as shingles, is a distinctive clinical condition caused by the reactivation of varicella zoster virus (VZV), which starts residing latently in the body after a primary varicella (chickenpox) infection, which may have occurred decades earlier. ${ }^{1,2}$ Reactivation of VZV can also produce chronic neuropathic pain without rash (zoster sine herpete), which can be more challenging to diagnose and may involve testing the cerebrospinal fluid. ${ }^{4,5}$
Pain Management Center, Stanfor Health Care, 450 Broadway Street, Pavilion A, Redwood City, CA 94063, USA

Tel +l 6507236238

Fax +l 6507213417

Email tmallick@stanfordhealthcare.org 


\section{Epidemiology}

In a survey conducted between 1988 and 1994 in the US, over $99 \%$ of adults aged $\geq 40$ years had serologic evidence of prior VZV infection and are therefore at risk of developing HZ. ${ }^{6}$ Approximately 1 million cases of $\mathrm{HZ}$ occur annually in the US, and one in every three persons develops $\mathrm{HZ}$ during their lifetime. ${ }^{7}$ It is estimated that $5 \%-20 \%$ of those with HZ go on to develop PHN. ${ }^{2,8}$ The frequency and severity of PHN increase with advancing age, occurring in $20 \%$ of people aged $60-65$ years who have had acute $\mathrm{HZ}$, and in more than $30 \%$ of people aged $>80$ years. ${ }^{1}$ In addition to age, risk factors for developing $\mathrm{PHN}$ after $\mathrm{HZ}$ include the presence of a prodrome (defined as pain and/or abnormal sensations before rash onset), severe rash (defined as $>50$ lesions: papules, vesicles, or crusted vesicles), and severe pain during the acute phase. ${ }^{9}$ A recent systematic review and meta-analysis also identified ophthalmic involvement as a risk factor. ${ }^{10}$ Additional possible risk factors included systemic lupus erythematosus, diabetes, and recent trauma. ${ }^{10}$ Immunocompromised patients are at increased risk of VZV reactivation as well as neurological complications. ${ }^{5}$

\section{$H Z$ and PHN pathophysiology and clinical presentation}

VZV is a highly contagious DNA virus that remains latent within the sensory ganglia following resolution of chickenpox, which usually occurs during childhood. ${ }^{2}$ During HZ, VZV is reactivated, travels back along the affected neurons away from the sensory ganglia, and propagates in the epidermis. A hallmark of $\mathrm{HZ}$ is that it is typically unilateral (ie, not crossing the midline), and in most cases only a single dermatome is affected. The erythematous maculopapular $\mathrm{HZ}$ rash is usually accompanied by pain and dysesthesia. The rash progresses to clear vesicles similar to the original chickenpox outbreak. Then, over a period of 48-72 hours, pustules form, ulcerate, and eventually scab over. Scabs fall off in 2-3 weeks and scarring may occur. ${ }^{9}$

PHN occurs in the same dermatomes as the $\mathrm{HZ}$ rash, and stems from damage to peripheral and central neurons that may be a byproduct of the immune/inflammatory response that accompanied VZV reactivation and migration. ${ }^{2,11}$ When damaged, peripheral and central nerve fibers may develop a lower threshold for action potentials, discharge spontaneously, and exhibit disproportionate responses to stimuli, resulting in peripheral sensitization and pain without painful stimuli (allodynia). ${ }^{2,11}$ Patients with PHN experience three major types of pain: 1) constant pain without a stimulus (often described as burning, aching, or throbbing), 2) intermittent pain without a stimulus (often described as stabbing, shooting, or electric shock-like), and 3) pain brought on by a stimulus but is disproportionate to the stimulus (hyperalgesia), ${ }^{2,3}$ enduring for at least 3 months after healing of the HZ-related skin rash. In addition, patients may experience a variety of abnormal sensations (dysesthesias or paresthesias). Patients with PHN report decreased quality of life and interference with activities of daily living that may affect physical, psychological, and social aspects of their lives as well as their ability to function. ${ }^{12}$

\section{Diagnosis of PHN}

A history of $\mathrm{HZ}$ and the nature of the pain are critical parameters of a PHN diagnosis. Thus, obtaining a detailed medical history and including symptoms and vaccination history are very important, as is performing a careful physical examination with a focus on qualifying the pain and its impact on daily life. ${ }^{13,14}$ Areas previously affected by $\mathrm{HZ}$ may show evidence of cutaneous scarring, and the site of the pain should be inspected for rash, color changes, and edema. Areas of sensory abnormalities, including allodynia (painful response to normally innocuous stimuli), hyperalgesia (heightened pain response), or dysesthesia (unpleasant and abnormal sensation), in the affected area should be assessed for sensitivity to touch (eg, light touch with a cotton swab or small paintbrush; pinprick with a safety pin or a wooden toothpick), for thermal response to warm or cold objects (eg, metal thermorollers), and/or for response to vibration (eg, using a $128 \mathrm{~Hz}$ tuning fork). ${ }^{13}$ Complementary quantitative sensory testing can be used along with bedside examination to provide additional information about the functional status of the somatosensory system. ${ }^{13,15}$ Pain intensity and quality should be assessed using an appropriate pain scale, based on the patient's ability to communicate - a numerical rating scale (usually an 11-point scale: from 0 , no pain, to 10 , severe pain), a visual analog scale, or verbal descriptor scale (eg, McGill Pain Questionnaire). ${ }^{13}$ The impact of pain on the quality of life should be evaluated, usually by interview, but structured questionnaires can also be used. ${ }^{13}$

\section{Management of PHN}

Approaches to PHN management include preventing HZ, and thus possibly PHN, through vaccination and/or antiviral treatment, and administering specific medications to treat PHN pain. ${ }^{1,14,16,17}$ 


\section{Prevention of PHN}

The best way to prevent PHN is to avoid infection with VZV. For children born after the introduction of varicella vaccine in the US in 1995 and who have received the chickenpox vaccination, this is a real possibility. ${ }^{18}$ But for adults who contracted chickenpox as children, and who therefore have latent VZV, the best strategy to prevent VZV reactivation is to be vaccinated with the live attenuated shingles vaccine (Zostavax ${ }^{\circledR}$; Merck \& Co, Inc., Whitehouse Station, NJ, USA) approved for use in individuals aged $\geq 50$ years. ${ }^{19}$ The vaccine has been shown to be effective in reducing the incidence of $\mathrm{HZ}$, the burden of illness due to infection, and the incidence of PHN. Results of the Shingles Prevention Study involving 38,546 patients aged $\geq 60$ years vaccinated against $\mathrm{HZ}$ showed a $61.1 \%$ reduction of $\mathrm{HZ}$ burden of illness following vaccination compared to placebo. ${ }^{20}$ Given the short time the vaccine has been available, there is insufficient data to support its efficacy in the long-term prevention of PHN. ${ }^{16,21}$ Also, despite the availability of the vaccine, $<30 \%$ of adults aged $\geq 60$ years reported having had the vaccination in a 2014 survey. ${ }^{22}$

Prompt treatment of $\mathrm{HZ}$ with oral antiviral agents (acyclovir, famciclovir, or valacyclovir) slows the production of the virus and decreases the viral load in the dorsal root ganglia. ${ }^{1}$ Although there is some evidence that antiviral therapy may reduce the incidence and severity of PHN, especially when administered early in the disease, the evidence is somewhat inconsistent. ${ }^{1}$

\section{Treatment options for PHN}

PHN may persist for years and is difficult to treat. The safety and tolerability of pharmacologic therapies are important issues to consider as PHN affects primarily an older population. ${ }^{2,3,12}$ Once PHN has been diagnosed, treatment should be directed at pain control and minimizing treatment-related adverse events. No single best treatment has been identified.

Tricyclic antidepressants (TCAs), gabapentin, and pregabalin are generally the drugs of first choice for the treatment of PHN. Current guidelines recommend treatment of PHN in a hierarchical manner, with calcium channel $\alpha 2-\delta$ ligands (gabapentin and pregabalin), TCAs (amitriptyline, nortriptyline, or desipramine), or topical lidocaine patches as first-line drugs; opioids and topical capsaicin patch or cream as secondor third-line treatment options; or combination therapies with different mechanisms of action (Table 1). ${ }^{1,14,16,23,24}$

Prior to instituting an individual treatment plan, healthcare professionals, including nurses, should carefully evaluate patients' concomitant medications. Elderly patients in particular are more likely to have physical and/or cognitive comorbidities, and are more likely to be using other medications. ${ }^{25}$ Potential drug interactions occurring in elderly patients may lead to serious or even fatal adverse events. ${ }^{26}$ Adverse responses to medications are more prevalent in the older adult population, and polypharmacy, inappropriate use, and poor compliance are contributing risk factors. ${ }^{27}$ Furthermore, many oral medications require careful titration to the optimal dosage and multiple daily dosing, and may be accompanied by bothersome adverse effects. ${ }^{15,23}$ Consequently, patients may not reach the target therapeutic dosage or may stop taking the medication because of side effects. ${ }^{28}$ Thus, patients should be educated on appropriate dosing, titration if applicable, the importance of adherence to treatment, and possible side effects. It is also important to set expectations with respect to how long it might take to attain maximum pain relief. To ensure the optimal effectiveness of the treatment, clear communication with the patient, frequent monitoring of adverse reactions, and patient satisfaction with the treatment are essential. ${ }^{27}$ At each patient visit, current pain levels, location of pain, and pain quality should be reassessed, and the patient's ability to perform daily activities should be discussed. Response to current interventions and any side effects or difficulties with the treatment regimen should also be discussed.

\section{Tricyclic antidepressants}

TCAs such as nortriptyline (Pamelor, Aventyl), desipramine (Norpramin), and amitriptyline (Vanatrip, Elavil, Endep) are used frequently in PHN treatment. ${ }^{1,14,16,23,29}$ Although standardly used, TCAs should be used with caution in the elderly, ${ }^{30}$ and in those with heart disease, epilepsy, or glaucoma. The practitioner should be familiar with TCA mechanism of action and counsel the patient that it may take weeks for the medication to be fully effective, and that TCAs are associated with significant systemic adverse events (most notably anticholinergic), cardiotoxicity, and other side effects (Table 1).

\section{Calcium channel $\alpha 2-\delta$ ligands}

For patients with moderate to severe PHN who have contraindications to or intolerance of TCAs, consider treatment with gabapentin or pregabalin. Gabapentin and pregabalin are effective treatments for neuropathic pain. Gabapentin, first approved as an anticonvulsant medication, ${ }^{31}$ was noted to have beneficial effects on neuropathic pain. Conse- 
Table I Treatment options for postherpetic neuralgia

\begin{tabular}{|c|c|c|}
\hline Therapy & Dosage & Most common adverse reactions in clinical trials \\
\hline \multicolumn{3}{|l|}{ First line } \\
\hline \multicolumn{3}{|l|}{ Calcium channel $\alpha_{2}-\delta$ ligands } \\
\hline Gabapentin & $\begin{array}{l}\text { Starting dose } 100-300 \mathrm{mg} \text { at bedtime or } 100-300 \mathrm{mg} \\
\text { three times daily. Increase dose by } 100-300 \mathrm{mg} \text { three } \\
\text { times every } \mathrm{I}-7 \text { days as tolerated up to a maximum of } \\
3,600 \mathrm{mg} / \text { day. }{ }^{\mathrm{a}, \mathrm{b}, 29}\end{array}$ & $\begin{array}{l}\text { Dizziness, somnolence, peripheral edema, diarrhea, } \\
\text { asthenia, infection, dry mouth, constipation, nausea, } \\
\text { vomiting, accidental injury, ataxia, abnormal thinking, } \\
\text { blurred vision. }{ }^{\text {, } 33}\end{array}$ \\
\hline Gastroretentive gabapentin & $\begin{array}{l}\text { Starting dose } 300 \mathrm{mg} / \text { day. Increase dose by } 300 \mathrm{mg} / \text { day } \\
\text { on days } 2,3,7, \mathrm{II} \text {, and } 15 \text { up to a maximum dose of } \\
\mathrm{I}, 800 \mathrm{mg} / \text { day. }^{\mathrm{b}, 35}\end{array}$ & $\begin{array}{l}\text { Dizziness, somnolence, headache, peripheral edema, } \\
\text { diarrhea. }{ }^{, 35}\end{array}$ \\
\hline Gabapentin enacarbil & $\begin{array}{l}\text { Starting dose } 600 \mathrm{mg} \text { in the morning. Increase dose to } \\
600 \mathrm{mg} \text { twice daily on day } 4 .^{\mathrm{b}, 37}\end{array}$ & $\begin{array}{l}\text { Dizziness, somnolence, headache, nausea, fatigue/ } \\
\text { asthenia, peripheral edema, insomnia, weight gain. }{ }^{c, 37}\end{array}$ \\
\hline Pregabalin & $\begin{array}{l}\text { Starting dose } 50 \mathrm{mg} \text { three times daily or } 75 \mathrm{mg} \text { twice } \\
\text { daily as tolerated. Increase dose to } 300 \mathrm{mg} / \text { day after } \\
3-7 \text { days, and then by } 150 \mathrm{mg} / \text { day every } 3-7 \text { days as } \\
\text { tolerated up to a maximum of } 600 \mathrm{mg} / \text { day. }{ }^{\text {a,b,2, }} \text {. }\end{array}$ & $\begin{array}{l}\text { Dizziness, somnolence, peripheral edema, ataxia, } \\
\text { blurry vision, abnormal gait, headache, weight gain, } \\
\text { confusion, edema, abnormal thinking, abnormal vision, } \\
\text { pain, accidental injury, constipation, diplopia, amnesia, } \\
\text { infection, flatulence, vomiting, incoordination, speech } \\
\text { disorder, bronchitis.,4l }\end{array}$ \\
\hline \multicolumn{3}{|l|}{ Tricyclic antidepressants } \\
\hline $\begin{array}{l}\text { Nortriptyline } \\
\text { Desipramine }\end{array}$ & $\begin{array}{l}\text { Starting dose } 25 \mathrm{mg} \text { at bedtime. Increase dose } \\
\text { by } 25 \mathrm{mg} / \text { day every } 3-7 \text { days as tolerated up to a } \\
\text { maximum of } 150 \mathrm{mg} / \text { day; if blood concentration of } \\
\text { active medication and its metabolite are }<100 \mathrm{ng} / \mathrm{mL} \text {, } \\
\text { continue titration with caution., }{ }^{\text {a, }, 29}\end{array}$ & Dry mouth, weight gain, drowsiness. ${ }^{52}$ \\
\hline \multicolumn{3}{|l|}{ Topical agents } \\
\hline Lidocaine $5 \%$ patch & Apply every 4-12 hours; up to three patches per day. ${ }^{29}$ & $\begin{array}{l}\text { Application-site reactions (blisters, bruising, burning } \\
\text { sensation, depigmentation, dermatitis, discoloration, } \\
\text { edema, erythema, exfoliation, irritation, papules, } \\
\text { petechiae, pruritus, vesicles), asthenia, confusion, } \\
\text { disorientation, dizziness, headache, hyperesthesia, } \\
\text { hypoesthesia, lightheadedness, metallic taste, nausea, } \\
\text { nervousness, pain exacerbated, paresthesia, somnolence, } \\
\text { taste alteration, vomiting, visual disturbances such as } \\
\text { blurred vision, flushing, tinnitus, and tremor. }{ }^{53}\end{array}$ \\
\hline \multicolumn{3}{|l|}{ Second or third line } \\
\hline \multicolumn{3}{|l|}{ Opioid analgesics } \\
\hline Oxycodone & $\begin{array}{l}\text { Titration: morphine oral equianalgesic dosages of } \\
\text { I0-15 mg every } 4 \text { hours; after I- } 2 \text { weeks, convert } \\
\text { total daily dosage to long-acting opioid analgesic and }\end{array}$ & $\begin{array}{l}\text { Constipation, nausea, somnolence, dizziness, pruritus, } \\
\text { vomiting, headache, dry mouth, asthenia, sweating, } \\
\text { insomnia, asthenia. }{ }^{54,55}\end{array}$ \\
\hline Morphine & $\begin{array}{l}\text { continue short-acting agent as needed; no maximum } \\
\text { dosage, but consider evaluation by a pain specialist at }\end{array}$ & $\begin{array}{l}\text { Constipation, dizziness, sedation, nausea, vomiting, } \\
\text { sweating, dysphoria, euphoric mood, somnolence. } .^{56,57}\end{array}$ \\
\hline Methadone & doses $\geq 120 \mathrm{mg}$ daily or equianalgesic dosage. ${ }^{29}$ & $\begin{array}{l}\text { Lightheadedness, dizziness, sedation, nausea, vomiting, } \\
\text { and sweating. }{ }^{58}\end{array}$ \\
\hline Tramadola,d & $\begin{array}{l}\text { Starting dose at } 50 \mathrm{mg} \text { one to two times per day; } \\
\text { titrated in } 50-100 \mathrm{mg} \text { increments in divided doses } \\
\text { every } 3-7 \text { days; maximum dosage } 400 \mathrm{mg} / \text { day ( } 100 \mathrm{mg} \\
\text { four times per day); maximum dosage for the elderly } \\
300 \mathrm{mg} / \text { day. }{ }^{29}\end{array}$ & $\begin{array}{l}\text { Dizziness, nausea, constipation, headache, somnolence, } \\
\text { flushing, pruritus, vomiting, insomnia, dry mouth, } \\
\text { diarrhea, asthenia, postural hypotension, sweating, } \\
\text { anorexia. }^{58}\end{array}$ \\
\hline \multicolumn{3}{|l|}{ Topical agents and creams } \\
\hline Capsaicin $8 \%$ patch & $\begin{array}{l}\text { Up to four patches for I hour every } 3 \text { months or } \\
\text { longer; needs to be administered by a physician or } \\
\text { trained personnel; a topical anesthetic is applied to the } \\
\text { affected area before capsaicin patch. } .^{59}\end{array}$ & $\begin{array}{l}\text { Application-site reactions (pain, burning, erythema, } \\
\text { pruritus, papules, edema), nausea, vomiting. }{ }^{59}\end{array}$ \\
\hline Capsaicin $0.075 \%$ cream & Apply three to five times per day. & \\
\hline
\end{tabular}

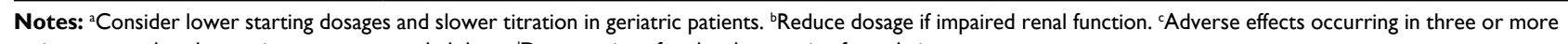
patients treated at the maximum recommended dose. ${ }^{d}$ Dosages given for the short-acting formulation. 
quently, an immediate-release formulation of gabapentin (Neurontin $^{\circledR}$; Pfizer, Inc., New York, NY, USA) was approved for the treatment of PHN in $2002 .{ }^{32}$ As a result of its nonlinear pharmacokinetics whereby drug absorption and bioavailability decrease with increasing dose, and its short half-life, immediate-release gabapentin is dosed three times daily. In clinical studies, the efficacy of the immediate-release formulation of gabapentin in PHN was demonstrated over a range of dosages from $1,800 \mathrm{mg} /$ day to $3,600 \mathrm{mg} /$ day, but without additional benefit for dosages $>1,800 \mathrm{mg} /$ day. ${ }^{33}$ Treatment was associated with a high incidence of dizziness and somnolence, which may impact the adherence and/or the ability to achieve a therapeutic dose. ${ }^{32}$ A retrospective study of a large medical claims database revealed that only $14 \%$ of patients ever reached the therapeutically effective dosage of $1,800 \mathrm{mg} /$ day, and for those who did, it required 10 weeks. ${ }^{34}$

To simplify titration and dosing regimens, and to improve drug absorption and bioavailability, enhanced versions of gabapentin were developed and approved for the treatment of PHN: gastroretentive gabapentin (Gralise ${ }^{\circledR}$; Depomed, Inc., Newark, CA, USA), ${ }^{35}$ approved in $2011,{ }^{36}$ and gabapentin enacarbil (Horizant ${ }^{\circledR}$; XenoPort, Inc., Santa Clara, CA, USA), ${ }^{37}$ approved in $2012 .{ }^{38}$ Gabapentin enacarbil is a gabapentin prodrug and has more widely distributed sites of intestinal absorption than the immediate-release formulation, and drug exposure is more proportional to the drug dosage. Gabapentin enacarbil is dosed twice daily and is titrated over 4 days to a dosage of $1,200 \mathrm{mg} /$ day. ${ }^{37}$ Direct comparisons between the two formulations have not been performed, and it is unknown whether gabapentin enacarbil has better efficacy in PHN management than the immediate-release formulation of gabapentin. ${ }^{39}$

Gastroretentive gabapentin employs a polymer-based technology that swells the tablet when it comes in contact with gastric fluid. When taken once a day with food, the swollen tablet remains in the stomach for 8-10 hours, gradually releasing gabapentin to its site of absorption in the upper small intestine. The effective dosage of $1,800 \mathrm{mg}$ is reached using a 2 -week titration schedule, and $95 \%$ of patients were able to complete the titration to an efficacious dosage in clinical studies. ${ }^{40}$ The efficacy of gastroretentive gabapentin in PHN management has been established in two Phase III, placebo-controlled trials, without a direct comparison with an immediate-release formulation. ${ }^{40}$

Pregabalin (Lyrica ${ }^{\circledR}$; Pfizer) was granted approval for the treatment of PHN in 2005. ${ }^{41,42}$ A therapeutic dosage for pregabalin (150-600 mg/day, taken in two or three doses per day) is lower than for gabapentin, and a 1-week titration is recommended to reach the effective dosage. ${ }^{41}$ However, a retrospective study of pregabalin usage from a large database of medical claims revealed that patients took approximately 5 weeks to reach a dosage of $\geq 150 \mathrm{mg} /$ day ( $87 \%$ of patients reached that dosage) and 9 weeks to reach a dosage of $\geq 300 \mathrm{mg} /$ day ( $27 \%$ of patients reached that dosage) ${ }^{34}$ When pregabalin was directly compared with immediate-release gabapentin in a small study in which 32 patients with PHN substituted gabapentin with pregabalin at one-sixth dosage of gabapentin, there were no significant changes in pain evaluated by a visual analog scale after the substitution of gabapentin with pregabalin. ${ }^{43}$

The adverse event profiles for the calcium channel $\alpha 2-\delta$ ligands are similar; however, the type of adverse events varies significantly (Table 1). ${ }^{33,35}$ The most common adverse events reported in clinical studies were dizziness and somnolence, and dose-related rates of adverse events were the highest for immediate-release gabapentin (24\%-31\% for dizziness and $17 \%-27 \%$ for somnolence) ${ }^{40}$ Incidences of dizziness and somnolence reported for gastroretentive gabapentin were $11 \%$ and $5 \%$, respectively. ${ }^{40}$ Compared with immediate-release gabapentin, dosage-related risk of dizziness and somnolence with pregabalin, dosed twice daily, is also lower (7\%-28\% and 5\%-14\%, respectively). Rates of these adverse events with gabapentin enacarbil dosed twice daily are slightly lower $(17 \%-30 \%$ and $10 \%-14 \%$, respectively). Warnings and precautions for all calcium channel $\alpha 2-\delta$ ligands, as with all central nervous system agents, include a warning for increased risk of suicidal thoughts or behaviors..$^{33,44}$

Calcium channel $\alpha 2-\delta$ ligands are an especially attractive option for older patients, who often take several concomitant medications, because they are not metabolized by the cytochrome P450 system drug-metabolizing enzymes and therefore have low propensity for drug-drug interactions. ${ }^{33,35,37,41}$ The only caveat is that since calcium channel $\alpha 2-\delta$ ligands are excreted by the kidneys, daily dosing should be adjusted in patients with reduced renal function. ${ }^{33,35,37,41}$ Also, since no large head-to-head studies comparing the various calcium channel $\alpha 2-\delta$ ligands have been conducted to compare their efficacy, ${ }^{23}$ which gabapentinoid is the most efficacious for the treatment of PHN remains an open question. The frequency of daily dosing, simplicity of titration, ability to reach effective dosages, and safety profiles of different $\alpha 2-\delta$ ligands can help health-care professionals to decide which agent is the most appropriate for each PHN patient. 


\section{Serotonin norepinephrine reuptake inhibitors}

A recent systematic review and meta-analysis of pharmacotherapies for neuropathic pain in adults found a high quality of evidence for the first-line use of the serotonin norepinephrine reuptake inhibitors duloxetine or venlafaxine. ${ }^{17}$ However, the recommendation for their use applies to neuropathic pain in general. Other guidelines ${ }^{16}$ recommend the use of serotonin norepinepherine reuptake inhibitors (SNRIs) for painful diabetic neuropathy but not for PHN, citing a paucity of clinical evidence. ${ }^{16,29}$

\section{Opioid analgesics}

The use of opioids in PHN management guidelines has changed from first-line to second- or third-line therapies over time, which likely reflects increasing concern over their potential for misuse, their side effect profiles, and the potential complete response using adjuvant monotherapy. ${ }^{14,16}$ Opioids can be used at low doses and titrated to provide relief, possibly while awaiting therapeutic benefits from other first-line agents (ie, tricyclic drugs, gabapentin, or pregabalin), at which point opioids could be tapered off. Opioids also can be used cautiously for intractable PHN that is refractory to treatment with other treatments. Opioids used in treating PHN pain include oxycodone, morphine, methadone, and tramadol. Tramadol has proven less effective than strong opioids in clinical trials for PHN and is considered a mild opioid, while oxycodone, morphine, and methadone are considered strong opioids. ${ }^{14,16,23,29}$

\section{Topical therapies}

For patients with mild to moderate localized pain from PHN and for patients with PHN who do not desire therapy with oral drugs, topical therapies with capsaicin and lidocaine may be considered. Special consideration must be made for education on appropriate application.

In a meta-analysis of four randomized, controlled trials involving 1,272 patients with PHN, all efficacy outcomes were significantly better in patients treated with a single application of $8 \%$ topical capsaicin compared with those treated with $0.014 \%$ topical capsaicin. ${ }^{45}$ However, in pivotal trials, the capsaicin $8 \%$ patch was associated with notable administration site reactions, including erythema (63\%), pain $(43 \%)$, pruritus $(6 \%)$, and papules $(6 \%)$. Transient increases in pain are also commonly observed on the day of treatment. ${ }^{46}$

Capsaicin $0.075 \%$ cream has shown inconsistent and only modest efficacy in clinical trials, and current guidelines state that analgesia provided by capsaicin cream is below the threshold for a clinically important effect. ${ }^{16}$
The use of 5\% lidocaine patches has been shown both in clinical practice and in various clinical trials to provide patients with improved quality of life and reduced pain, particularly when combined with other proven analgesics for PHN. However, it should be noted that for all patients, the lidocaine patch cannot be used on open lesions.

In a systematic review, data from a few small, relatively low-quality placebo-controlled trials and open-label studies suggested that topical lidocaine (5\%) is beneficial for pain relief in patients with PHN. ${ }^{47}$ However, given the paucity of evidence and shortcomings of the included trials, no firm conclusions can be made regarding the efficacy of topical lidocaine for the treatment of PHN.

In another systematic review of the literature on PHN (using the National Library of Medicine's Medline database and the Cochrane Library database), the authors determined the absolute reduction rate, the number needed to treat, $95 \%$ confidence interval for the number needed to treat, and the number needed to harm for successful therapies of PHN. TCAs, gabapentin, pregabalin, opioids, and lidocaine patch were all found to be effective in reducing the pain of PHN. ${ }^{48}$

Interestingly, in a retrospective review $(\mathrm{N}=8)$ in elderly patients, use of a $5 \%$ lidocaine patch not only provided good pain relief, but was also associated with a $66 \%$ reduction in the painful area after 3 months. ${ }^{49}$ The authors speculate that in addition to its primary mechanism of blocking voltage-gated sodium channels, lidocaine's ability to desensitize TRPA1 channels may provide additional protection from primary and secondary sensitization, accounting for the reduction in the size of the painful area ${ }^{49}$ Due to the excellent safety and tolerability of the lidocaine patch, it may be of particular value in treating frail and elderly patients.

\section{Combination therapies}

A treatment plan combining analgesics with different mechanisms of action may provide the best overall therapeutic effect, particularly the combination of an oral agent with topical lidocaine $5 \%$ patch, or a combination of gabapentin with opioids or a TCA..$^{14,23,29}$ The combination of the lidocaine $5 \%$ patch and pregabalin was effective in patients with PHN who did not previously respond to either medication as monotherapy. ${ }^{14,16}$ Side effects were similar to those associated with the lidocaine patch and pregabalin alone, with applicationsite reactions, dizziness, and somnolence as most common adverse events. Also, the combination of immediate-release gabapentin $(\leq 3,600 \mathrm{mg} /$ day $)$ and nortriptyline $(\leq 100 \mathrm{mg} /$ day $)$ was significantly superior in relieving pain to either treatment as monotherapy in a clinical trial, with no new or higher 
occurrence of adverse events. ${ }^{14,16}$ Finally, combined morphine and immediate-release gabapentin decreased pain more than either medication alone, ${ }^{14,16}$ although the clinical meaningfulness of the observed $20 \%$ improvement in pain intensity over placebo is modest, and secondary outcome measurements were not consistently superior to either medication as monotherapy. The gabapentin-morphine combination also resulted in a high frequency of adverse events during and after titration period, which included constipation, sedation, dry mouth, vomiting, cognitive dysfunction, dizziness, nausea, ataxia, and edema. ${ }^{16}$

\section{Additional options}

Intrathecal glucocorticoid injections are another option for patients with intractable pain refractory to the above measures. However, intrathecal glucocorticoid injections are not useful for PHN involving the trigeminal nerve..$^{50}$

\section{Future directions}

$\mathrm{PHN}$ is a painful and burdensome condition that can compromise patient function and quality of life. Health-care professionals play a key role in helping to ameliorate the pain caused by PHN through diligent assessment and early recognition of the problem; recommending evidence-based pharmacologic modalities to manage the long-term pain of PHN; and monitoring patient adverse events, adherence to treatment, expectations, and responses to treatment in the elderly population most at risk. Nurses and nurse practitioners are especially crucial in establishing communication with patients and encouraging the initiation of appropriate painrelieving treatments, leading to better outcomes in patients. ${ }^{51}$

\section{Acknowledgments}

This review was sponsored by Depomed, Inc. Writing and editorial assistance was provided to the authors by Iwona Bucior and Helen Nicely of Depomed, Inc.

\section{Disclosure}

Theresa Mallick-Searle is on the speakers' bureau for Allergan, Inc., and Depomed, Inc. Brett Snodgrass is on the speakers' bureau for Depomed, Inc., Iroko Pharmaceuticals, AstraZeneca, Purdue Pharma, and McNeil Pharma. Jeannine M Brant is on the speakers' bureau for Genentech and Insys. The authors report no other conflicts of interest in this work.

\section{References}

1. Fashner J, Bell AL. Herpes zoster and postherpetic neuralgia: prevention and management. Am Fam Physician. 2011;83(12):1432-1437.

2. Gharibo C, Kim C. Neuropathic pain of postherpetic neuralgia. Pain Med News. 2011;9:84-92.
3. Tontodonati M, Ursini T, Polilli E, Vadini F, Di Masi F, Volpone D, Parruti G. Post-herpetic neuralgia. Int J Gen Med. 2012;5:861-871.

4. Gilden D, Cohrs RJ, Mahalingam R, Nagel MA. Neurological disease produced by varicella zoster virus reactivation without rash. Curr Top Microbiol Immunol. 2010;342:243-253.

5. Nagel MA, Gilden D. Complications of varicella zoster virus reactivation. Curr Treat Options Neurol. 2013;15(4):439-453.

6. Kilgore PE, Kruszon-Moran D, Seward JF, et al. Varicella in Americans from NHANES III: implications for control through routine immunization. J Med Virol. 2003;70(Suppl 1):S111-S118.

7. Harpaz R, Ortega-Sanchez IR, Seward JF; Advisory Committee on Immunization Practices (ACIP) Centers for Disease Control and Prevention (CDC). Prevention of herpes zoster: recommendations of the Advisory Committee on Immunization Practices (ACIP). MMWR Recomm Rep. 2008;57(RR-5):1-30.

8. Klompas M, Kulldorff M, Vilk Y, Bialek SR, Harpaz R. Herpes zoster and postherpetic neuralgia surveillance using structured electronic data. Mayo Clin Proc. 2011;86(12):1146-1153.

9. Nagasako EM, Johnson RW, Griffin DR, Dworkin RH. Rash severity in herpes zoster: correlates and relationship to postherpetic neuralgia. J Am Acad Dermatol. 2002;46(6):834-839.

10. Forbes HJ, Thomas SL, Smeeth L, Clayton T, Farmer R, Bhaskaran K, Langan SM. A systematic review and meta-analysis of risk factors for postherpetic neuralgia. Pain. 2016;157(1):30-54.

11. Woolf CJ, Mannion RJ. Neuropathic pain: aetiology, symptoms, mechanisms, and management. Lancet. 1999;353(9168):1959-1964.

12. Drolet M, Brisson M, Schmader KE, et al. The impact of herpes zoster and postherpetic neuralgia on health-related quality of life: a prospective study. CMAJ. 2010;182(16):1731-1736.

13. Haanpaa M, Attal N, Backonja M, et al. NeuPSIG guidelines on neuropathic pain assessment. Pain. 2011;152(1):14-27.

14. Nalamachu S, Morley-Forster P. Diagnosing and managing postherpetic neuralgia. Drugs Aging. 2012;29(11):863-869.

15. Backonja MM, Attal N, Baron R, et al. Value of quantitative sensory testing in neurological and pain disorders: NeuPSIG consensus. Pain. 2013;154(9):1807-1819.

16. Argoff CE. Review of current guidelines on the care of postherpetic neuralgia. Postgrad Med. 2011;123(5):134-142.

17. Finnerup NB, Attal N, Haroutounian S, et al. Pharmacotherapy for neuropathic pain in adults: a systematic review, meta-analysis and updated NeuPSIG recommendations. Lancet Neurol. 2015;14(2): 162-173.

18. Welsby PD. Chickenpox, chickenpox vaccination, and shingles. Postgrad Med J. 2006;82(967):351-352.

19. Zostavax ${ }^{\circledR}$ (zoster vaccine live) [package insert]. Whitehouse Station, NJ: Merck \& Co, Inc.; 2014.

20. Oxman MN. Zoster vaccine: current status and future prospects. Clin Infect Dis. 2010;51(2):197-213.

21. Gagliardi AM, Gomes Silva BN, Torloni MR, Soares BG. Vaccines for preventing herpes zoster in older adults [review]. Cochrane Database Syst Rev. 2012;10:CD008858.

22. Williams WW, Lu PJ, O'Halloran A, et al; Centers for Disease Control and Prevention (CDC). Surveillance of Vaccination Coverage Among Adult Populations - United States, 2014. MMWR Surveill Summ. 2016;65(1):1-36.

23. Dworkin RH, O'Connor AB, Backonja M, et al. Pharmacologic management of neuropathic pain: evidence-based recommendations. Pain. 2007;132(3):237-251.

24. Centre for Clinical Practice at NICE (UK) - National Institute for Health and Care Excellence: Clinical Guidelines. Neuropathic Pain: The Pharmacological Management of Neuropathic Pain in Adults in Non-specialist Settings. London: National Institute for Health and Care Excellence, UK; 2013.

25. Hines LE, Murphy JE. Potentially harmful drug-drug interactions in the elderly: a review. Am J Geriatr Pharmacother. 2011;9(6):364-377.

26. Routledge PA, O'Mahony MS, Woodhouse KW. Adverse drug reactions in elderly patients. Br J Clin Pharmacol. 2004;57(2):121-126. 
27. Massengill JS, Kittredge JL. Practical considerations in the pharmacological treatment of postherpetic neuralgia for the primary care provider. J Pain Res. 2014;7:125-132.

28. Selph S, Carson S, Fu R, Thakurta S, Low A, McDonagh M. Drug Class Review: Neuropathic Pain: Final Update 1 Report. Portland (OR): Oregon Health \& Science University; 2011.

29. Dworkin RH, O'Connor AB, Audette J, et al. Recommendations for the pharmacological management of neuropathic pain: an overview and literature update. Mayo Clin Proc. 2010;85(3 Suppl):S3-14.

30. Campanelli CM. American Geriatrics Society updated Beers Criteria for potentially inappropriate medication use in older adults. J Am Geriatr Soc. 2012;60(4):616-631.

31. Dolphin AC. Calcium channel alpha2-delta subunits in epilepsy and as targets for antiepileptic drugs. In: Noebels JL, Avoli M, Rogawski MA, Olsen RW, Delgado-Escueta AV, editors. Jasper's Basic Mechanisms of the Epilepsies. Bethesda, MD: National Center for Biotechnology Information (US); 2012.

32. Irving G. Once-daily gastroretentive gabapentin for the management of postherpetic neuralgia: an update for clinicians. Ther Adv Chronic Dis. 2012;3(5):211-218.

33. Neurontin ${ }^{\circledR}$ (gabapentin) [package insert]. New York, NY: Parke-Davis Division of Pfizer, Inc.; 2015.

34. Johnson P, Becker L, Halpern R, Sweeney M. Real-world treatment of post-herpetic neuralgia with gabapentin or pregabalin. Clin Drug Investig. 2013;33(1):35-44.

35. Gralise ${ }^{\circledR}$ (gabapentin) [package insert]. Newark, CA: Depomed, Inc.; 2012.

36. Chen C, Han CH, Sweeney M, Cowles VE. Pharmacokinetics, efficacy, and tolerability of a once-daily gastroretentive dosage form of gabapentin for the treatment of postherpetic neuralgia. J Pharm Sci. 2013;102(4):1155-1164.

37. Horizant ${ }^{\circledR}$ (gabapentin enacarbil) [package insert]. Santa Clara, CA: XenoPort, Inc; 2013.

38. Kume A. Gabapentin enacarbil for the treatment of moderate to severe primary restless legs syndrome (Willis-Ekbom disease): 600 or 1,200 mg dose? Neuropsychiatr Dis Treat. 2014;10:249-262.

39. Thomas BM, Farquhar-Smith P. Gabapentin enacarbil extended release for the treatment of postherpetic neuralgia in adults. Ther Clin Risk Manag. 2013;9:469-475.

40. Rauck RL, Irving GA, Wallace MS, Vanhove GF, Sweeney M. Oncedaily gastroretentive gabapentin for postherpetic neuralgia: integrated efficacy, time to onset of pain relief and safety analyses of data from two phase 3, multicenter, randomized, double-blind, placebo-controlled studies. J Pain Symptom Manage. 2013;46(2):219-228

41. Lyrica $^{\circledR}$ (pregabalin) [package insert]. New York, NY: Parke-Davis Division of Pfizer Inc; 2013.
42. Cappuzzo KA. Treatment of postherpetic neuralgia: focus on pregabalin. Clin Interv Aging. 2009;4:17-23.

43. Ifuku M, Iseki M, Hidaka I, Morita Y, Komatus S, Inada E. Replacement of gabapentin with pregabalin in postherpetic neuralgia therapy. Pain Med. 2011;12(7):1112-1116.

44. Patorno E, Bohn RL, Wahl PM, Avorn J, Patrick AR, Liu J, Schneeweiss $\mathrm{S}$. Anticonvulsant medications and the risk of suicide, attempted suicide, or violent death. JAMA. 2010;303(14):1401-1409.

45. Derry S, Sven-Rice A, Cole P, Tan T, Moore RA. Topical capsaicin (high concentration) for chronic neuropathic pain in adults [review]. Cochrane Database Syst Rev. 2013;2:CD007393.

46. Qutenza ${ }^{\circledR}$ (capsaicin) [package insert]. Ardsley, NY: Acorda Therapeutics, Inc.; 2013

47. Derry S, Wiffen PJ, Moore RA, Quinlan J. Topical lidocaine for neuropathic pain in adults [review]. Cochrane Database Syst Rev. 2014;7:CD010958

48. Dubinsky RM, Kabbani H, El-Chami Z, Boutwell C, Ali H; Quality Standards Subcommittee of the American Academy of Neurology. Practice parameter: treatment of postherpetic neuralgia: an evidencebased report of the Quality Standards Subcommittee of the American Academy of Neurology. Neurology. 2004;63(6):959-965.

49. Casale R, Di Matteo M, Minella CE, Fanelli G, Allegri M. Reduction of painful area as new possible therapeutic target in post-herpetic neuropathic pain treated with 5\% lidocaine medicated plaster: a case series. J Pain Res. 2014;7:353-357.

50. Bajwa ZH, Ortega E. Postherpetic neuralgia. UptoDate 2016. Available from: http://www.uptodate.com/contents/postherpetic-neuralgia. Accessed May 25, 2016.

51. Mann E. Neuropathic pain: could nurses become more involved? Br J Nurs. 2008;17(19):1208-1213.

52. Derry S, Wiffen PJ, Aldington D, Moore RA. Nortriptyline for neuropathic pain in adults [review]. Cochrane Database Syst Rev. 2015;1:CD011209.

53. Lidoderm ${ }^{\circledR}$ (lidocaine patch 5\%) [package insert]. Malvern, PA: Endo Pharmaceuticals, Inc.; 2015.

54. Oxycontin ${ }^{\circledR}$ (oxycodone $\mathrm{HCl}$ ) [package insert]. Stamford, CT: Purdue Pharma L.P.; 2015.

55. Roxicodone ${ }^{\mathbb{B}}$ (oxycodone hydrochloride tablets USP) [package insert]. Hazelwood, MO: Mallinckrodt, Inc.; 2014.

56. Morphine Oral Solution (morphine sulfate) [package insert]. Hazelwoood, MO: Mallinckrodt, Inc.; 2014.

57. MS CONTIN ${ }^{\circledR}$ (morphine sulfate extended-release tablets) [package insert]. Hazelwood, MO: Mallinckrodt, Inc.; 2014.

58. ULTRAM ${ }^{\circledR}$ ER (tramadol) [package insert]. Titusville, NJ: Janssen Pharmaceuticals, Inc.; 2014.

59. Qutenza ${ }^{\circledR}$ (capsaicin) $8 \%$ patch [package insert]. Ardsley, NY: Acorda Therapeutics, Inc.; 2013.
Journal of Multidisciplinary Healthcare

\section{Publish your work in this journal}

The Journal of Multidisciplinary Healthcare is an international, peerreviewed open-access journal that aims to represent and publish research in healthcare areas delivered by practitioners of different disciplines. This includes studies and reviews conducted by multidisciplinary teams as well as research which evaluates the results or conduct of such teams or health

\section{Dovepress}

care processes in general. The journal covers a very wide range of areas and welcomes submissions from practitioners at all levels, from all over the world. The manuscript management system is completely online and includes a very quick and fair peer-review system. Visit http://www.dovepress.com/ testimonials.php to read real quotes from published authors. 